\title{
Valorization of Phosphate Waste Sludge as a Nonhazardous Fire Resistant Material added to Concrete mix
}

\author{
H. M. Shaker ${ }^{1 *}$, , Shimaa, M. Abdel Moneim ${ }^{2}$, FA. Refaie ${ }^{1}$, Hanan S. Ibrahim ${ }^{2}$ \\ ${ }^{1}$ Building Physics Department, Housing and Building National Research Center, \\ ${ }^{1}$ Building Materials and Quality Control Department, Housing and Building National Research Center, \\ Cairo, Egypt. \\ ${ }^{2}$ Water Pollution Research Department, National Research Center, El-Buhouth St., Dokki, \\ Cairo, Egypt.
}

\begin{abstract}
Phosphate waste sludge (PWS) generated from a phosphate unit of an automotive manufacturing plant was investigated by X-ray Fluorescence and total heavy metals content and metal Leachability using Toxicity characteristic Leachate procedure (TCLP). Addition of different percentages of (PWS) to a concrete mix of Portland cement)was used for the solidification and stabilization $(S / S)$ process to immobilize the hazardous contamination of metals within the (PWS) as well as to create a construction matrix capable to be used as fire resistant material. The Solidification/Stabilization (S/S) concrete mixtures were prepared, then after a molding time of 24 hour, the samples were exposed to curing conditions that had a constant temperature $\left(20{ }^{\circ} \mathrm{C}\right)$ and a constant relative humidity. Investigation of the obtained specimens containing PWS as additive (control specimen, $1 \%$ and 3\% PWS) after curing in water for 28 days was done by measuring both, compressive strength and Fire resistance properties. The fire testing was done up to a temperature of $1000{ }^{\circ} \mathrm{C}$, the results show that concrete mix containing (PWS) of $3 \%$ have an excellent Fire resistance compared to the pure concrete, and also higher than specimen with $1 \%$ (PWS). The degree of fire resistance was (around on hour and 15 minute). Compressive strength of our specimens was decreased by increasing the percentage of PWS added. A noticeable decrease in the value of compressive strength of specimens containing (PWS) comparing to that of control concrete: from $31.2 \mathrm{~N} / \mathrm{mm}^{2}$ for control sample to a value of 19.8 $\mathrm{N} / \mathrm{mm}^{2}$ of specimen containing $3 \%$ PWS. Micro structure of our mixes after compression testing was studied using scanning electron microscopy (SEM).Propagation of cracks and micro cracks was observed for all specimens. Needle - like structure (Ettringite) also was observed in the SEM image.
\end{abstract}

KEY WORDS: Phosphate sludge; Solidification / Stabilization; Fire resistance, Compressive strength, SEM.

\section{INTRODUCTION}

Rapid industrialization over the past few decades has strongly increased the amount of hazardous industrial waste produced all over the world. As a result, these wastes need to be managed correctly in order to minimize their harmful effects on human health and of course on the environment.Traditional disposal of waste material cause many problems to the Environment, so Re-use of waste materials in Construction sector as a constituent to strongly improve some properties of concrete become of very great importance. This sludge is one of the most problematic types of waste encountered in automotive industries. Solidification/stabilization (S/S) was recognized by the Environment Protection Agency (EPA) as the best demonstrated available treatment technology for land disposal of hazardous wastes [1] .

In Solidification/stabilization (S/S) process, different binding materials have been used such as ordinary Portland cement (OPC), fly ash, pozzolans, Zeolite, lime, etc., [2, 3] but the most common one was (OPC).

Concrete which is considered the core of construction all over the world is mainly composed of matrix, aggregate and interfacial transition zones (ITZ) [4]. The weakest part of the concrete is (ITZ), such zone is considered to cause lower compressive strength than aggregate and also hardened cement [5].Approximately from $65 \%$ to $75 \%$ of concrete volume is occupied by aggregates. The 
commonly used aggregate are stable up to a temperature around $350{ }^{\circ} \mathrm{C}$, but when the temperature rises to a value near to $600{ }^{0} \mathrm{C}$, some chemical and physical changes take place in the aggregate which leads to an increase in the volume of the aggregates [6].The addition of specific materials like those obtained from agricultural or industrial wastes to Ordinary Portland cement (OPC) concrete could improve its performance when exposed to highly elevated Temperatures (Fire). When concrete exposed to Fire, some types of deterioration will occur like destruction of the bond between cement paste and the aggregate, and a gradual damage of hardened cement paste. The effect of highly elevated temperature on concrete is mainly observed by loss in mechanical properties and deterioration of concrete. Many scientists attribute that behaviour to the formation of cracks and microcracks on the surface of the concrete [7]. The degradation in the properties of concrete at elevated temperature is mainly due to both mechanical and chemical changes that occurring in the aggregate and cement paste [8].

\subsection{Materials and Methods}

\subsection{Materials}

Materials used in producing the concrete mixes are: cement, coarse aggregate (CA), fine aggregate (FA), superplasticizer and water plus Phosphate waste sludge (PWS). The used cement is Ordinary Portland cement CEM I 42.5N complies with the Egyptian standard Specification ESS 4756 -1 /2013. The Coarse aggregate is crushed stone (dolomite) with maximum nominal size of $10 \mathrm{~mm}$ and has specific unit weight of 2.6. The fine aggregate is siliceous sand with fineness modulus of 2.8 and has specific unit weight of 2.5.Both coarse and fine aggregate comply with the requirements of the Egyptians Code ECP $203-2018$. Superplasticizer admixture (type G) was used to obtain workable concrete. The Chemical composition of Phosphate waste sludge (PWS) is presented in Table 1 which comes from analysis using X-ray Fluorescence (XRF), PANALYTICAL, MODEL AXIOS 3400 , Netherland. . The particle size of (PWS) by sieve analysis was found below $75 \mu \mathrm{m}$ and its specific gravity is 1.679 .

Table 1. Chemical composition of Phosphate waste sludge (PWS)

\begin{tabular}{|c|c|c|c|c|c|c|c|c|c|c|c|c|}
\hline $\begin{array}{c}\text { Chemical } \\
\text { composition }\end{array}$ & $\mathrm{Sio}_{2}$ & $\mathrm{Al}_{2} \mathrm{O}_{3}$ & $\mathrm{Fe}_{2} \mathrm{O}$ & $\mathrm{CaO}$ & $\mathrm{MgO}$ & $\mathrm{SO}_{3}$ & $\mathrm{Na}_{2} \mathrm{O}$ & $\mathrm{K} 2 \mathrm{O}$ & $\mathrm{P}_{2} \mathrm{O}_{5}$ & $\mathrm{MnO}$ & $\mathrm{ZnO}$ & L.O.I \\
\hline$(\mathrm{wt} \%)$ & 1.88 & $\mathbf{0 . 4 6}$ & $\mathbf{2 3 . 0 0}$ & 0.41 & 0.76 & 0.43 & 3.74 & 2.34 & 52.70 & 1.66 & 7.77 & 2.35 \\
\hline
\end{tabular}

\subsection{Concrete Mix Proportioning}

Concrete mixes were prepared. All mixtures were of cement content of $350 \mathrm{Kg} / \mathrm{m}^{3}$ and dolomite to sand ration of (0.6 : 0.4).The Phosphate waste sludge (PWS) amorphous powder was employed in amounts of (1\% and $3 \%$ ) by Concrete weight. Due to the High water absorption of the waste powder, the amount of water was adjusted according to the waste powder content keeping free water to cement ration of 0.5 . Superplasticizer dosage varied from $1.9 \%$ to $2.2 \%$ of cement content to achieve the required level of workability presented in slump of $100 \pm 2 \mathrm{~mm}$. Chemical composition of the used Portland Cement CEM I $42.5 \mathrm{~N}$ is presented in Table 2 .

Table 2. Chemical composition of the used Portland cement

\begin{tabular}{|c|c|r|r|c|c|c|c|c|c|c|c|c|}
\hline composition & $\mathrm{Sio}_{2}$ & $\mathrm{Al}_{2} \mathrm{O}_{3}$ & $\mathrm{Fe}_{2} \mathrm{O}$ & $\mathrm{CaO}$ & $\mathrm{MgO}$ & $\mathrm{SO}_{3}$ & $\mathrm{Na}_{2} \mathrm{O}$ & $\mathrm{K} 2 \mathrm{O}$ & $\mathrm{P}_{2} \mathrm{O}_{5}$ & $\mathrm{MnO}$ & $\mathrm{ZnO}$ & L.O.I \\
\hline$(\mathrm{wt} \%)$ & 21.00 & 6.80 & 2.90 & 61.80 & 3.80 & 2.50 & 0.50 & 0.40 & --- & --- & --- & 1.60 \\
\hline
\end{tabular}

\subsection{Mixing Procedures}

Mixing was done in a small rotatory drum. In the first step of the mixing, the fine and coarse aggregates were dry mixed for 30 second. The second step consists of adding the cement and mixed with aggregates for 30 second. (PWS) powder was added and a further dry mixing of materials for 30 second. The Superplasticizer was added to the mixing water prior to its addition to dry constituents and mixing for 2 minutes before the mixing machine was stopped.

\subsection{Casting of Specimens}

Cubes of size $150 \mathrm{~mm}$ x $150 \mathrm{~mm}$ x $150 \mathrm{~mm}$ were cast to measure the compressive strength of test specimens. All the specimens were de-molded at the age of 24 hour and were cured in the water tank at room temperature up to the required age of testing which is (28 day).

\subsection{Concrete Tests}

Compressive Strength and Fire Resistance tests were conducted on the three concrete mixtures. Compressive strength tests were conducted according to Standard specification BS EN 12390 - 3: 2009.Three cubes of 150 mm side length were cast for each mixture. For Fire Reissuance tests one prism mold of 300 x 300 x100 mm was prepared for each mixture according to the standard test method ASTM E 119 - 16 a "Standard Test Methods for Fire Tests of Building Construction and Materials .After we have carried out compressive strength and Fire tests, microstructure analysis was done for both crushed and Fired Concrete samples using Scanning electron microscopy (SEM). 


\subsection{The Fuel Burning Furnace.}

The internal size of the furnace allows a sample of $(300 \times 300 \mathrm{~mm})$ length by width dimensions. K- type thermocouple is used to measure the temperature inside the furnace. The furnace was designed to attain a maximum temperature of $1200{ }^{0} \mathrm{C}$. Then these specimens were allowed to cool down to room temperature for 24 hours and then taken out from the furnace. Fire Testing was carried out in our Fire Laboratory at Housing and Building National Research Center (HBRC) Cairo, Egypt.

\subsection{The Solidification/Stabilization Process}

The Solidification/Stabilization $(\mathbf{S} / \mathbf{S})$ concrete mixtures were prepared in a small rotary drum and were molded into cubic test molds $150 \times 150 \times 150 \mathrm{~mm}^{3}$ in dimension. After a molding time of 24 hour, the samples were exposed to curing conditions that had a constant temperature $\left(20^{\circ} \mathrm{C}\right)$ and a constant relative humidity inside a curing bath. The concrete samples with different phosphate to cement (P/C) ratios were produced with the substitution of sand for phosphate sludge in the P/C percentage of 0 , 1 , 5,10 , and $20 \%$. And the addition of cement to each sample was constant. For further investigation of the behavior of PWS after the Solidification/Stabilization process, Toxicity Characteristic Leaching Procedure (TCLP) was applied. The TCLP was done according to (USEPA method 1311). Finally the leached metals were analyzed in the filtrate according to the "Standard Methods for the Examination of Water and Waste water [9]. The weight loss of the solidified mixtures containing $1 \%$ of the phosphate sludge to the cement ratio and the blank were measured at the end of a 28-day curing period, according to the EN 12390-7 standards for the determination of the permeability of solidified mixtures.

\subsection{The Toxicity Characteristics Leaching Procedure (TCLP).}

The TCLP leaching experiments is designed to simulate the leaching conditions in the environment and to determine the amount of heavy metals that can be leached from the S/S samples. The test was conducted on the PWS sample and the S/S concrete mixtures with the different percentages of PWS. Table 4 presents the availability of $\mathrm{As}, \mathrm{Ba}, \mathrm{Cd}, \mathrm{Cr}, \mathrm{Pb}, \mathrm{Hg}, \mathrm{Se}$ and $\mathrm{Ag}$ in TCLP extracts. The results showed that the leached $\mathrm{Pb}, \mathrm{Cd}$ and $\mathrm{Cr}$ concentrations from PWS is higher than TCLP regulatory Level. While the leachable amount of metals from the $(\mathrm{S} / \mathrm{S})$ products are under the limit values.

\subsection{Microstructural analysis}

The Scanning electron microscope (SEM), model FEI (inspect S), Netherland was used for identification of the changes occurring in the microstructure of the concrete specimens after compression test and also after exposure to fire. The Chemical composition of Phosphate waste sludge (PWS) was measured by X-ray Fluorescence (XRF), PANALYTICAL, Model AXIOS 3400, Netherland.

\section{RESULTS AND DISCUSSION}

\subsection{Visual Observations of Concrete Specimens after Exposure to Fire}

The test specimens were exposed to fire at temperatures up to $1000{ }^{\circ} \mathrm{C}$ in the gas burning furnace. The starting point of Fire assessment of concrete is the visual observation of color change, cracking, and also spalling of concrete surface [10]. Due to the complex behavior of concrete with fire, phenomenon called explosive spalling still needs more explanation [11, 12]. Such a phenomena is usually assumed to occur only at high temperatures, but is was also observed that it may exist in the early stages of fire [13]. Then these specimens were allowed to cool down to room temperature for 24 hours and then taken out from the furnace.
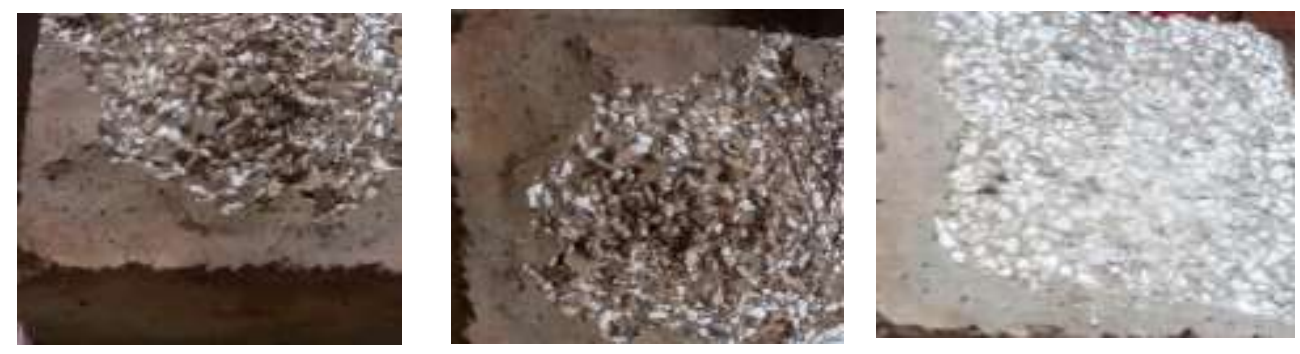

Figure 2. Images of Both Control concrete and specimens with $1 \%$ and $3 \%$ (PWS) from left to right after Fie Exposure.

\subsection{Effect of Fire}

In order to investigate the effects of Fire on our concrete specimens containing Phosphate waste sludge (PWS) which are [control concrete, $1 \%$ and 3\% PWS loaded concrete as Case study specimens], we should first know that relation between Concrete and fire is mainly a complicated issue, this is due to the composition of concrete and other extremely strong thermal conditions usually found in fire. Figure 2 is Time - Temperature curve containing the Standard Curve according to the Standard used in measurements and other three curves for our specimens. Figure 2 shows the effect of addition of PWS to concrete .The temperature measured for all specimens is the temperature of the unexposed surface. We noticed that control concrete specimen and after 30 minute exposure of Fire, Cracks begin to be generated at the thickness region of the specimen, which will be seen 
International Journal of Advances in Scientific Research and Engineering (ijasre), Vol 5 (9), September-2019

below in the Scanning electron microscope (SEM) image analysis. While concrete specimen containing (PWS) gives excellent degree of fire resistance.

Specimen with higher percentage of PWS (3\%) gives an excellent Fire resistance (around one hour and 15 minute fire resistance). This excellent fire resistance was due to increase of Self ignition property coming from the composition of Phosphate waste sludge (PWS).Dehydration of concrete and also its thermal expansion due to heating may lead to the formation of pores in the concrete rather than, or in addition to, explosive spalling. So formation of cracks in such situation may create pathways for fire to spread.

To study more details of the thermal response of concrete, Scientists go to undergo extensive testing, mostly based on standard heating curves and presented as a "fire resistance" time, typically a function of thickness or cover, for different types of concrete [14]. Many physical and chemical changes occur in concrete when subjected to heat $[\mathbf{1 5}, \mathbf{1 6}, \mathbf{1 7}]$.

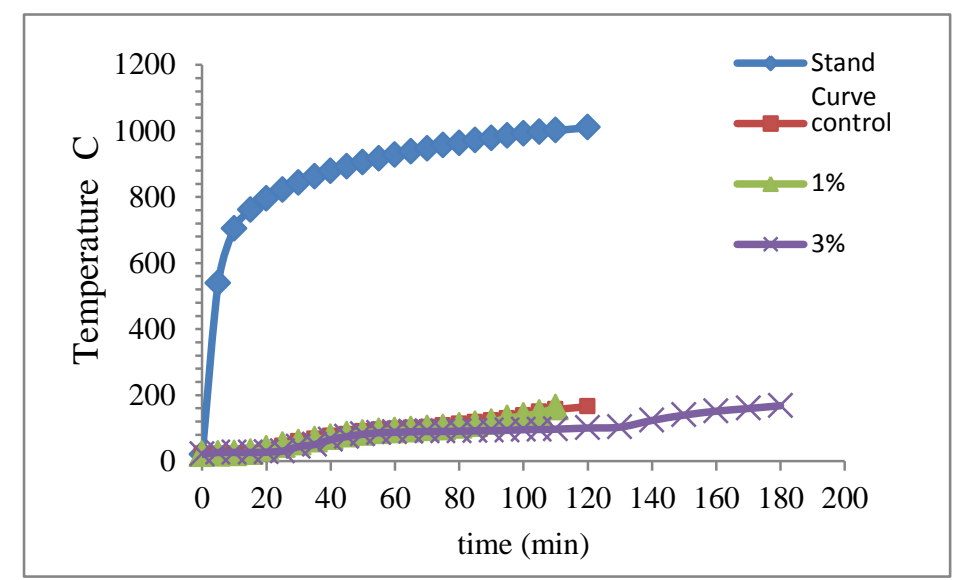

Figure 2. Time - Temperature Curve of Both Control and (PWS) loaded Concrete specimens.

\subsection{Compressive strength}

Portland cement gets its strength from the chemical reactions occur between the cement and water, i.e. through hydration process. We can say in other words that Silicates and aluminates in presence of water form products of hydration which in time produce the hard hydrated cement paste. One of the main properties of concrete is compressive strength, but when excessive amount of water used during mixing, this will lead to reduction in compressive strength, as the excess water will not be involved in hydration process and retain in concrete even after hardening. The effect of Phosphate waste sludge (PWS) on the compressive strength of concrete specimens is shown in Fig. 3. Both the mixes 1\% and 3\% (PWS) indicate downward trend in strength with increasing the content of (PWS). Such a trend was due to using excess water during mixing of concrete, as (PWS) powder absorbs water.

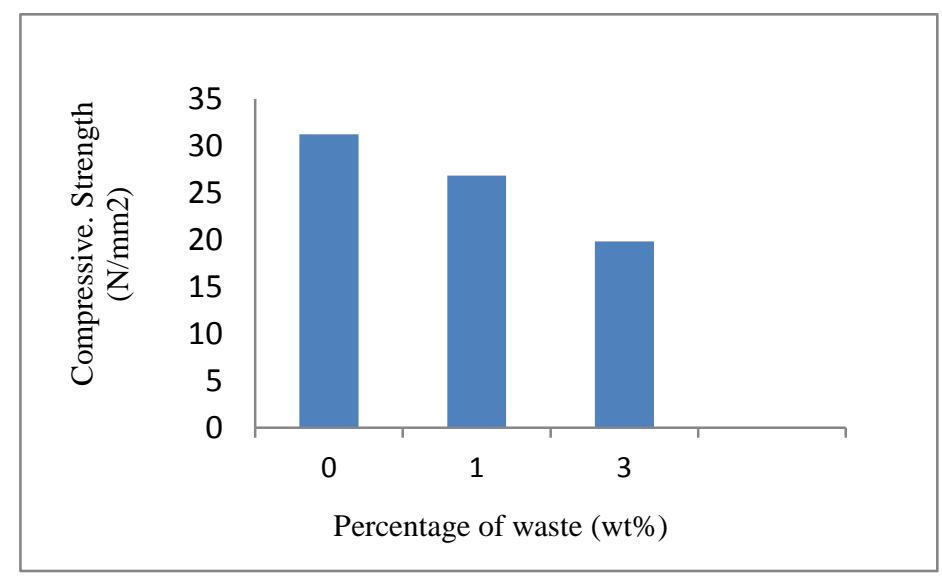

Figure 3. Compressive strength of concrete specimens at 28 day.

\subsection{Characterization of phosphate waste sludge.}

Characterization of the PWS using X-ray fluorescence (XRF) and their chemical compositions are listed in Tables 3. The obtained results show high contents of $\mathrm{P}_{2} \mathrm{O}_{5}(52.7 \mathrm{wt} \%), \mathrm{Fe}_{2} \mathrm{O}_{3}(23.0 \mathrm{wt} \%)$ and potential hazardous contaminants, such as $\mathrm{F}$ (1.47 wt \%), Cr (17 ppm), Pb (65 ppm), Cd (17.9 ppm) and Zn (7400 ppm). 
International Journal of Advances in Scientific Research and Engineering (ijasre), Vol 5 (9), September-2019

Table 3. Chemical and mineralogical composition of PWS.

\begin{tabular}{|c|c|c|c|c|c|c|c|}
\hline Constituents & (wt. \%) & Constituents & (wt. \%) & Metals & $(\mathbf{m g} / \mathbf{K g})$ & Metals & $(\mathbf{m g} / \mathbf{K g})$ \\
\hline $\mathrm{SiO}_{2}$ & 1.88 & $\mathrm{NiO}_{2}$ & 0.58 & As & 6.5 & $\mathrm{~Pb}$ & 65.2 \\
\hline $\mathrm{SO}_{3}$ & 0.43 & $\mathrm{~F}$ & 1.47 & $\mathrm{Cd}$ & 17.96 & $\mathrm{Zn}$ & 7400 \\
\hline $\mathrm{Al}_{2} \mathrm{O}_{3}$ & 0.46 & $\mathrm{SnO}_{2}$ & 0.26 & $\mathrm{Cr}$ & 17.42 & $\mathrm{Ni}$ & 3800 \\
\hline $\mathrm{MnO}$ & 1.66 & $\mathrm{Cl}$ & 0.1 & $\mathrm{Cu}$ & 16.4 & $\mathrm{P}$ & 107000 \\
\hline $\mathrm{Fe}_{2} \mathrm{O}_{3}{ }^{\text {tot. }}$ & 23.0 & $\mathrm{P}_{2} \mathrm{O}_{5}$ & 52.7 & $\mathrm{Fe}$ & 5696 & $\mathrm{Ca}$ & 2600 \\
\hline $\mathrm{CaO}$ & 0.41 & $\mathrm{MgO}$ & 0.76 & \multirow{3}{*}{ Mn } & \multirow{3}{*}{6170} & \multirow{3}{*}{ S } & \multirow{3}{*}{600} \\
\hline $\mathrm{Na}_{2} \mathrm{O}$ & 3.74 & $\mathrm{ZnO}$ & 7.77 & & & & \\
\hline \multicolumn{2}{|c|}{ L.O.I } & \multicolumn{2}{|c|}{2.35} & & & & \\
\hline
\end{tabular}

From XRD analysis, the chemical analysis confirms the mineral composition (Table 3) with four main phases: calcite, fluorapatite, dolomite and quartz. As well the content of organic compounds was carried out, it was found that the quantity of Polychlorinated biphenyl (PCBs) in sludge is less than the detection limit of analysis method ( $\mathrm{LOQ}=0.03 \mu \mathrm{g} / \mathrm{kg}$ ) (EPA 8082). Moreover, Poly aromatic hydrocarbons (PAHs) in sludge is less than the detection limit of analysis method ( $\mathrm{LOQ}=5 \mu \mathrm{g} / \mathrm{kg}$ ) (EPA-610). Total halogen in phosphate sludge was found to be less than $100 \mu \mathrm{g} / \mathrm{kg}$ (ASTM D 808). The obtained results that total aqueous hydrocarbons (TAQH) and total aromatic hydrocarbons (TAH) were detected with concentration of 95600 and 18800 $\mu \mathrm{g} / \mathrm{kg}$, respectively (EPA-8410; EPA-8020A).

\subsection{The Solidification/Stabilization process.}

The S/S concrete mixtures were produced by the addition of different percentages of $(0,1$ and $3 \%)$ PWS to a fixed S/S prepared concrete mixes (cement, coarse aggregate, fine aggregate, superplasticizer and water). Then these concrete mixtures were subjected to compressive strength, fire resistance and then analyzed.

\subsection{SEM Microstructural analysis}

\subsubsection{SEM analysis after Compression Test}

In order to investigate the morphology of Concrete mixes with the addition of $1 \%$ and $3 \%$ Phosphate waste sludge (PWS) at the age of 28 days, Scanning Electron Microscope (SEM) was used. The results are shown in Figure 4.The major binding phase of concrete is the amorphous calcium silicate hydrate gel, symbolized as $\mathrm{C}-\mathrm{S}-\mathrm{H}[18]$ In fact, $\mathrm{C}-\mathrm{S}-\mathrm{H}$ possesses an internal pore structure comprised of pores within several nanometers [19]. This fine porous structure, relative to that of a colloidal gel, creates a high interfacial surface area between solid phase and liquid phase. As we see in SEM micrograph of concrete specimen containing 3\% PWS in (Fig4, b and c) with 3,000 Magnification, Needle like structure is obviously appeared. Usually, if concrete is exposed to water for long periods of time, primary Ettringite can slowly dissolve and reform in voids or any available like microcracks. [20].

Also appearance of strong cracks and voids in SEM micrographs is due to the reduction in compressive strength coming from excess water used during concrete mix, this water may evaporate when exposed to the atmosphere and form these voids. The voids left are responsible for reduction of compressive strength.
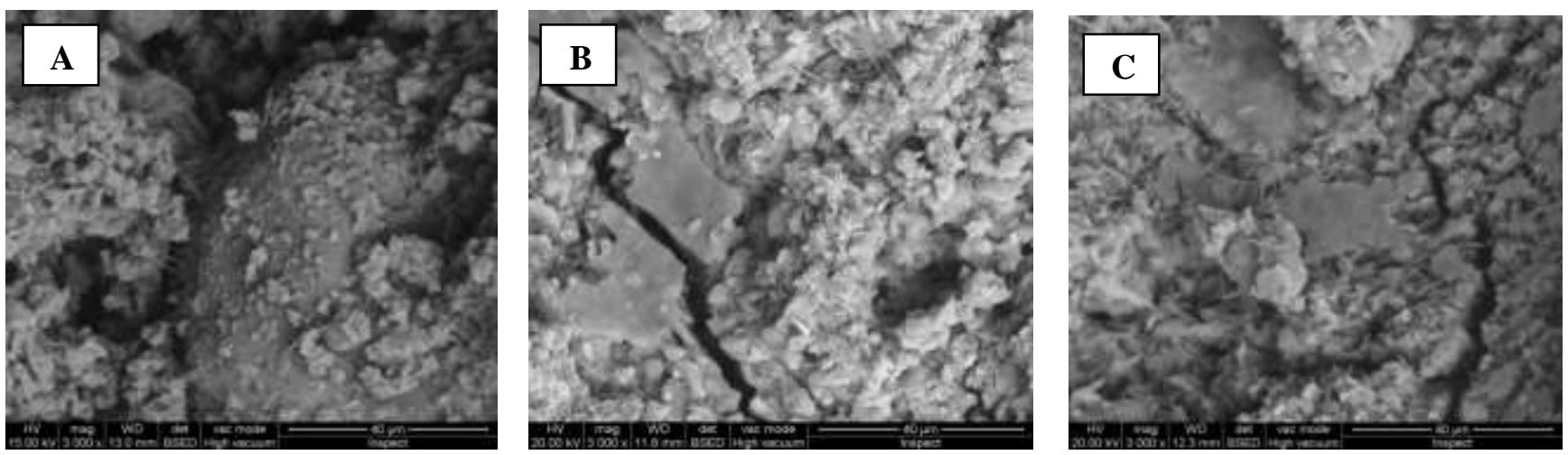

Fig 4. SEM micrograph of concrete specimens at age of 28 days (a) ControlConcrete, (b) Concrete with 1\% (PWS), (c) Concrete with $3 \%$ (PWS) after compression test. 


\subsubsection{SEM analysis after Exposure to Fire}

Figure 5 illustrates SEM micrograph of control concrete and specimens with (1\% 3\% PWS),the micrographs indicate the presence of compact strong structure. Calcareous aggregate like calcite, dolomite and magnetite dissociates at higher tempertaures (more than $600{ }^{\circ} \mathrm{C}$ ) into an oxide and carbon dioxide.So, mixing concrete with Phosphate waste sludge (PWS) with its chemical composition containing different metal oxides and also metals like $\mathrm{Zn}$ and Ni with high concentration give a strong effect in Fire Resistance.
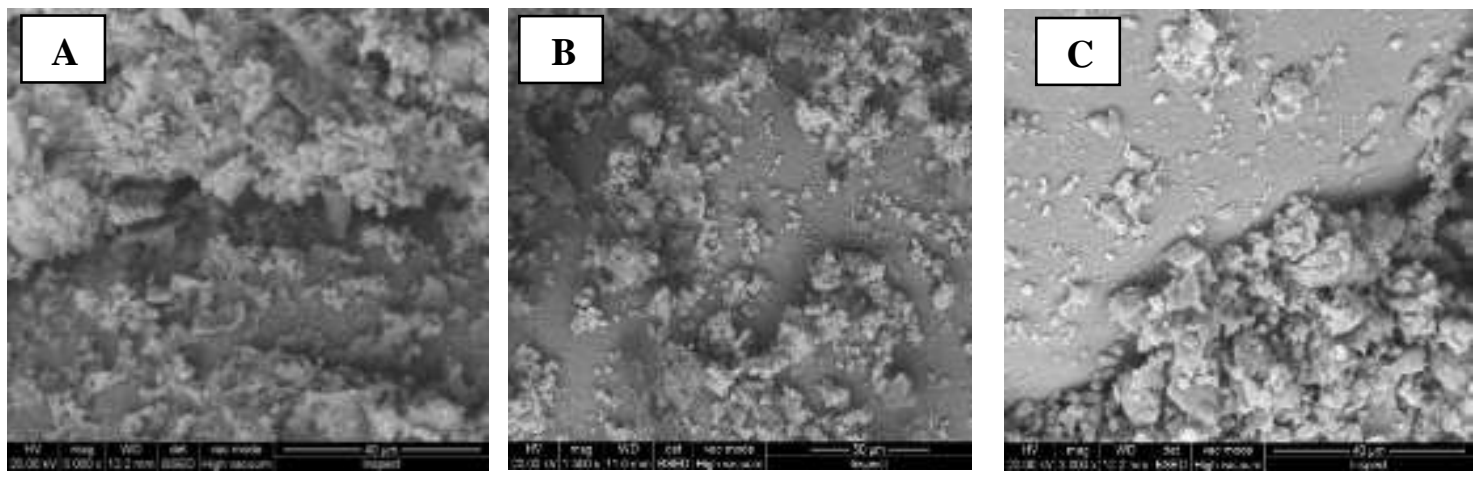

Fig 5. SEM micrograph of concrete specimens at the age of 28 days (a) Control Concrete (0\%),

(b) Concrete with 1\% (PWS), (c) Concrete with 3\% (PWS) after Fire.

\subsection{The Toxicity Characteristics Leaching Procedure (TCLP).}

The TCLP leaching experiments is designed to simulate the leaching conditions in the environment and to determine the amount of toxic substances that can be leached from the S/S samples. The test was conducted on the PWS sample and the S/S concrete mixtures with the different percents of PWS. Table 4 presents the availability of $\mathrm{As}, \mathrm{Ba}, \mathrm{Cd}, \mathrm{Cr}, \mathrm{Pb}, \mathrm{Hg}, \mathrm{Se}$ and $\mathrm{Ag}$ in TCLP extracts. The results showed that the leached $\mathrm{Pb}, \mathrm{Cd}$ and $\mathrm{Cr}$ concentrations from PWS is higher than TCLP regulatory Level. While the leachable amount of metals, volatile organic compounds, semivolatile organic compounds, organochlorine pesticides and chlorophenoxy acid herbicides from the S/S products are under the limit values. This may be due to many reasons such as the high $\mathrm{pH}$ of this concrete mixtures is effective in immobilizing these toxic metals, by precipitation and sorption reaction or by interactions between the hydration products of OPC and the metal ions within the PWS. Therefore, these S/S concrete mixtures considered non-hazardous in nature with respect to the present environmental regulations [21, 2].

Table 4. Heavy Metal Analysis in Leachate

\begin{tabular}{|l|c|c|c|c|r|r|}
\hline Parameters & LoQ* & $\begin{array}{c}\text { TCLP } \\
\text { Regulatory } \\
\text { Level } \\
\mathbf{m g / L}\end{array}$ & PWS & $\begin{array}{r}\text { S/S concrete } \\
(\mathbf{0 \%} \text { PWS })\end{array}$ & $\begin{array}{r}\text { S/S } \\
\text { concrete } \\
(\mathbf{1 \%} \text { PWS })\end{array}$ & $\begin{array}{r}\text { S/S } \\
\text { concrete } \\
(3 \% \text { PWS })\end{array}$ \\
\hline Arsenic & 0.001 & 5.0 & 0.05 & ND & ND & ND \\
\hline Barium & 0.001 & 100.0 & 0.035 & ND & ND & ND \\
\hline Cadmium & 0.002 & 1.0 & 1.5 & ND & ND & ND \\
\hline Chromium & 0.002 & 5.0 & 6.5 & ND & ND & ND \\
\hline Lead & 0.001 & 5.0 & 7.3 & ND & ND & ND \\
\hline Mercury & 0.0005 & 0.2 & ND & ND & ND & ND \\
\hline Selenium & 0.002 & 1.0 & ND & ND & ND & ND \\
\hline Silver & 0.002 & 5.0 & ND & ND & ND & ND \\
\hline
\end{tabular}
ND means $<\mathrm{L}$
*LOQ : limit of quantification

U.S. EPA, Training module on Hazardous Waste Identification (40 CFR Parts 261), Solid Waste and Emergency

Response (5305W), EPA 530-K-05-012 (2005).

Egyptian Environmental Affairs Agency (EEAA, 1994), Law No. 4 of 1994 on Environment.

\section{CONCLUSIONS}

The reduction of the compressive strength of concrete containing Phosphate waste sludge (PWS) is mainly due to the excess water of mixing which weakens the bonding of hydration products. The study reveals that when concrete mixes that contain 
phosphate waste sludge (PWS) are exposed to highly elevated temperature (Fire), the concrete resist fire for a pronounced period of time .The Toxicity Characteristics Leaching Procedure (TCLP) experiments is designed to simulate the leaching conditions in the environment and to determine the amount of heavy metals that can be leached from the S/S samples. it was found that the quantity of Polychlorinated biphenyl (PCBs) in sludge is less than the detection limit of analysis method $(\mathrm{LOQ}=0.03 \mu \mathrm{g} / \mathrm{kg})$. Moreover, Poly aromatic hydrocarbons (PAHs) in sludge is less than the detection limit of analysis method $(\mathrm{LOQ}=5 \mu \mathrm{g} / \mathrm{kg})$.

\section{ACKNOWLEDGMENT}

Special Thanks go to my Colleague at Fire Testing Lab at Housing and Building National Research Center HBRC, Prof. Dr. Sayed Shebl, head of Fire Lab., Dr. Mahmoud Mokhtar and Dr. Hamda Shoukry.

\section{REFERENCES}

[1]M.R. Lasheen, et al "Pozzolanic-based materials for stabilization /solidification of contaminated sludge with hazardous heavy metal: Case Study" Desalination and Water Treatment. (2013) 51/13-15, 2644-2655

[2] Qiao XC, Poon CS, Cheeseman CR. Investigation into the stabilization/solidification performance of Portland cement through cement clinker phases. J Hazard Mater 2007;139, 238-43.

[3] Azza M Ashmawy, et al "Immobilization of some metals in contaminated sludge by zeolite prepared from local materials" Toxicological \& Environmental Chemistry, (2012). 94, (9) 1657-1669.

[4] Mehta, P.K.; Monteiro, P.J.M. Concrete: Microstructure, Properties, and Materials; McGraw-Hill: London,UK, 2006.

[5] Ke, Y.; Ortola, S.; Beaucour, A.; Dumontet, H. Identification of microstructural characteristics in Light weight aggregate concretes by micromechanical modelling including the interfacial transition zone (ITZ). Cem.Concr. Res. 2010, 40, 1590-1600.

[6] Hager Gaweska, I, Behavior of cement concrete at high temperature. Bull. Polish Acad. Sci. Tech. Sci. 61, 2013, 145-154.

[7] Chen, B., Li, C., Chen, L, Experimental study of mechanical properties of normal-strength concrete exposed to high temperatures at an early age. Fire Saf. J. , 2009, 44, 997-1002.

[8] Phan, L, Fire performance of high-strength concrete: a report of the state-of the-art. Fire Res. 1996.

[9] Standard Methods for the Examination of Water and Wastewater. 23rd Edition America Public Health Association, Washington D.C (2017).

[10] Georgali B, Tsakiridis PE. Microstructure of fire-damaged concrete. Cement and Concrete Composites 2005; 27:255-259.

[11] Khoury G.A., Effect of fire on concrete and concrete structures, Progress in Structural Engineering and Materials, 2 (2000), 4, 429-447

[12] Tenchev, R. \& Purnell, P., An application of a damage constitutive model to concrete at high temperature and prediction of spalling, Int. J. Solids \& Structures, 42 (2005), 26, 6550-6565

[13] Canisius, T.D.G., Waleed, N. \& Matthews. S.L., Evaluation of effects of the fire test on Cardington concrete building, Proceedings (CIB Publication No. 290, eds. Shafi, F., Bukowski, R. \& Klemencic, R.), CIB-

CTBUH Int. Conf. on Tall Buildings, Kuala Lumpur, Malaysia, 20-23 October 2003, 353-360

[14] BS 8110-1:1997 and BS 8110-2:1985 "Structural use of concrete". BSI

[15] Khoury G.A., Effect of fire on concrete and concrete structures, Progress in Structural Engineering and Materials, 2 (2000), 4, 429-447.

[16] Bazant, Z.P. \& Kaplan, M.F., Concrete at High Temperatures, Longman, London, UK1996

[17] Carvel, R., Fire protection in Concrete Tunnels, in The Handbook of Tunnel Fire Safety (Eds. Beard, A. \& Carvel, R.) Thomas Telford, London, 2005

[18] H. F. W. Taylor, Cement Chemistry, 2nd ed. Thomas Telford, London (1997).

[19] H. M. Jennings, J. J. Thomas, J. S. Gevrenov, G. Constantinides, and F.-J. Ulm, "A Multi- Technique Investigation of the Nanoporosity of Cement Paste," Cem. Concr. Res., (2007), 37[3], 329-336.

[20] Lerch, William, Effect of SO3 Content of Cement on Durability of Concrete R \& D Serial No. 0285,Portlans Cement Association, Skokie, lllinois, 1945.

[21]. U.S. EPA, Training module on Hazardous Waste Identification (40 CFR Parts 261), Solid Waste and Emergency Response (5305W), EPA 530-K-05-012 (2005).

[22]. Egyptian Environmental Affairs Agency (EEAA, 1994), Law No. 4 of 1994 on Environment. 